\title{
THE DIRECT EFFECT OF MOTIVATION ON PROENVIRONMENTAL BEHAVIOR (PEB) AT SENIOR HIGH SCHOOL STUDENTS
}

\author{
Desi Eka Nur Fitriana ${ }^{1}$, Mieke Miyarsah ${ }^{2}$, Rusdi $^{2}$ \\ ${ }^{1}$ MTs. Nurul Ilmi, Jl. Raya Serang KM 15 Cikupa, Tangerang, Banten \\ ${ }^{2}$ Lecture of Biology Education, Jakarta State University, Jl. Rawamangun Muka, \\ Rawamangun, Pulo Gadung, East Jakarta \\ e-mail: desiekanf@gmail.com
}

\begin{abstract}
Proenvironmental behavior is a behavior that seeks to minimize the negative impact on the environment which is influenced by several factors, one of which is motivation. This study aims to analyze the direct effect of motivation on proenvironmental behavior. This research was conducted using a quantitative approach with a causal survey method and analyzed using path analysis. The number of samples used as respondents is 200 students of class XI MIA SMAN 1 Tangerang Regency. Based on the results of testing the hypothesis it can be concluded that there is a positive direct effect of personality on proenvironmental behavior with a path analysis coefficient of 0.159 . There is a positive direct effect of motivation on proenvironmental behavior with a path coefficient of 0.486 .
\end{abstract}

Keywords: Motivation, Pro Environment Behavior, Path Analysis.

\begin{abstract}
ABSTRAK
Perilaku proenvironmental adalah perilaku yang berupaya meminimalkan dampak negatif terhadap lingkungan yang dipengaruhi oleh beberapa faktor, salah satunya adalah motivasi. Penelitian ini bertujuan untuk menganalisis pengaruh langsung motivasi terhadap perilaku proenvironmental. Penelitian ini dilakukan dengan menggunakan pendekatan kuantitatif dengan metode survei kausal dan dianalisis menggunakan analisis jalur. Jumlah sampel yang digunakan sebagai responden adalah 200 siswa kelas XI MIA SMAN 1 Kabupaten Tangerang. Berdasarkan hasil pengujian hipotesis dapat disimpulkan bahwa ada pengaruh langsung positif kepribadian terhadap perilaku proenvironmental dengan koefisien analisis jalur sebesar 0,159. Ada pengaruh langsung positif dari motivasi pada perilaku proenvironmental dengan koefisien jalur 0,486.
\end{abstract}

Kata kunci: Motivasi, Pro Environment Behavior, Analisis Path. 


\section{INTRODUCTION}

Environment is everything that exists in nature including water, air, and land and living things (plants, animals and microorganisms) that live in it (Chiras, 1990). Over time, environmental conditions change due to various human activities in an effort to meet their needs. Human behavior in order to meet their needs often causes adverse effects on the environment such as soil, water and air. Such behavior can be in the form of use of transportation, use of inorganic materials and industrial activities. The use of transportation will have an impact on carbon dioxide emissions that pollute the air. The use of inorganic materials will cause waste because it cannot be decomposed easily and will damage soil fertility. Then, the presence of industrial activities in urban areas will provide waste that damages the soil and water. Human behavior above will cause an environmental problem in the form of environmental degradation (Gifford \& Nilsson, 2014). In addition, environmental problems are also enhanced by a lack of human awareness to maintain and improve the environment so that the quality of the environment decreases (Azzrai, et al., 2017).

Environmental problems are now a challenge for the government and society that must be resolved (Bronfman, et al., 2015). Environmental problems that begin in human actions, the solution to overcome the problem also lies in changes in human behavior (Manolas, 2015). Therefore, to overcome these environmental problems, community behavior must contribute positively to the environment, one of which is by adopting proenvironmentalal behavior patterns (Steg \& Vlek, 2009). Proenvironmental behavior is considered a behavior that aims to protect the environment or a form of respect for a healthy environment (Krajhanzl, 2010). Proenvironmental behavior is behavior that seeks to reduce the negative impact of one's actions on the environment. This proenvironmental behavior can be in the form of reducing consumption of resources and energy, using materials that are nontoxic, and reducing waste production (Kollmuss \& Agyeman, 2002).

This proenvironmental behavior must be instilled in each individual. One of his efforts through learning in this material is that proenvironmental behavior is expected to develop in students. The MARS model adapted from McShane \& Glinow (2015) illustrates that proenvironmental behavior is influenced by several factors and mediated by several factors. Motivation factor is one of the factors found in someone who influences proenvironmental behavior. Kurisu (2015) argues that proenvironmental behavior can be carried out with the motivation to preserve the environment and actually contribute to the delivery of the environment. Motivation means the power that drives a person to generate and 
direct behavior (Shunck, 2012). Someone who is intrinsically motivated will act proenvironmental behavior because someone believes that what he does is right to do (Linder, 2015). Werff, et al. (2012) stated that intrinsic motivation succeeded in mediating the relationship between environmental self-identity and environmentally-friendly behavior. Therefore, motivation can be a mediator in forming students' proenvironmentalal behavior.

Based on previous explanations, the proenvironmental behavior of students is one of the behaviors that are expected to be able to reduce environmental problems which in its formation are influenced by several factors. Therefore, research is needed on the effect of motivation on proenvironmental behavior.

\section{METHODOLOGY}

This study used a quantitative approach with a survey method. This study used path analysis (path analysis) with exogenous variables (X1), namely personality and endogenous variables (X2), namely proenvironment behavior. The samples of this study taken by multistage random sampling technique. The number of samples in this study were 200 students. Data collection in this study used questionnaire opinion.

\section{RESULTS AND DISCUSSION}

The results of the study obtained data for the description. The results of the study show that the highest score of motivation is 95 . This highest score means that students have enthusiasm for students in environmental activities, love to support the environment, strive to always support the environment, prioritize activities and environmental flexibility and carry out positive activities for their environment.

Then the highest score for proenvironmental behavior is 88. this means that students' behavior in saving energy, likes the use of public transportation, behavior of reducing the amount of waste, likes perilkau that are more environmentally friendly, saves water energy and always tries to reduce and reuse or recycle garbage.

\section{Linearity Test Simple Regression Model and Significance between Motivation and Proenvironmental behavior $(\alpha=0.05)$}

Regression test was carried out using a simple linear regression test. Based on the results of the calculation of the data to compose a model of the regression equation between motivation and proenvironmental behavior, a constant value of $a=27,270$ and $a b$ value of 0.551 are obtained (Table 2). Therefore the regression equation model between motivation 
and environmental behavior is $\dot{X}_{2}=27,270+0,551 X_{1}$. This can be interpreted that each increase in 1 motivation score $\left(\mathrm{X}_{1}\right)$ will be followed by an increase in proenvironmental behavior of 0.551 in the constant 27.270 through the regression model $\dot{X}_{2}$.

Table 1. Regression of motivation and proenvronmental behavior

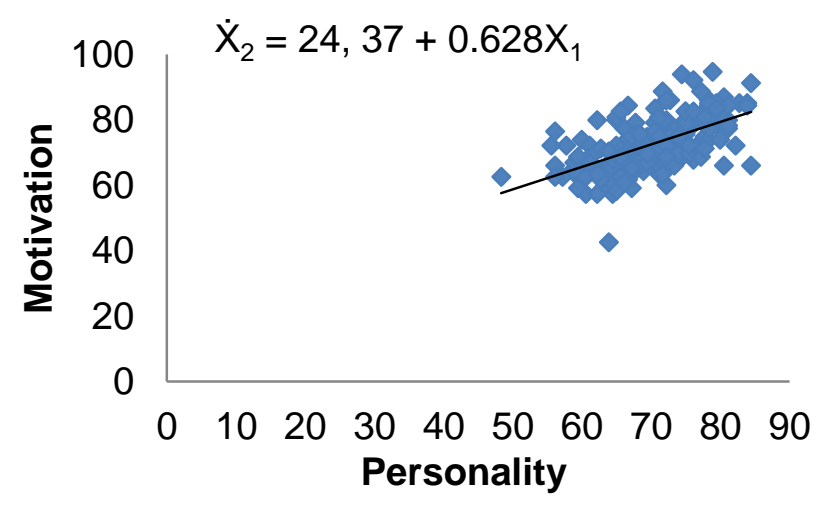

\begin{tabular}{|ccccccc|}
\hline \multirow{2}{*}{ Model } & \multicolumn{2}{c}{ Unstandardized Coefficients } & $\begin{array}{c}\text { Standardized } \\
\text { Coefficients }\end{array}$ & \multirow{2}{*}{ t } & Sig. \\
\cline { 2 - 5 } & B & Std. Error & Beta & & 6,737 & 0,000 \\
\hline \multirow{2}{*}{1} & 27,270 & 4,048 & & & 9,959 & 0,000 \\
\hline
\end{tabular}

Figure1. The Simplified Linear Regression Model between Personality and Motivation

Based on the significance test results obtained, the significance value is $<0.05$ so that the equation between personality and motivation variables is significant. Based on the results of the linear equation regression test obtained a significant value> 0.05 so that the regression equation of the motivational variable and proenvironmental behavior is linear or form a point distribution that resembles a linear line (Figure 1).

\section{Correlation Test}

The correlation between motivation and proenvironmental behavior is equal to $\mathrm{r}_{12}=$ 0.578 with a significance value $<0.05$. Therefore the correlation between motivation and proenvironmental behavior of students is very significant. This means that the higher the motivation of students, the higher the students proenvironmental behavior. 
Table 2. Correlation Test Results

\begin{tabular}{|c|c|c|c|}
\hline & & Personality & PEB \\
\hline Motivation & $\begin{array}{l}\text { Pearson Corellation } \\
\text { Sig. (2-Tailed) } \\
\text { N }\end{array}$ & $\begin{array}{l}1 \\
200\end{array}$ & $\begin{array}{l}0,578 \\
0,000 \\
200\end{array}$ \\
\hline PEB & $\begin{array}{l}\text { Pearson Corellation } \\
\text { Sig. (2-Tailed) } \\
\text { N }\end{array}$ & $\begin{array}{l}0,578 \\
0,000 \\
200\end{array}$ & $\begin{array}{l}1 \\
200\end{array}$ \\
\hline
\end{tabular}

\section{Path Analysis Test}

The path coefficient that shows motivation directly influences proenvironmental behavior is $\mathrm{p}_{21}$. Based on the calculations that have been done, the $\mathrm{p}_{21}$ path analysis analysis is obtained as 0.486 and the tcount is 6.00 and the ttable value for $\alpha=0.05$ is 1.644 . Therefore, the value of tcount> ttable so that motivation has a direct effect on proenvironmental behavior. The path coefficient of 0.486 means that the direct effect of motivation on proenvironmental behavior is 0.486 . thus students' proenvironmental behavior is directly influenced positively by student motivation (Table 3).

Table 3. The Result of Path Analysis

\begin{tabular}{|l|l|l|l|l|l|}
\hline \multicolumn{1}{|c|}{ Direct Effect } & $\begin{array}{c}\text { Path Koeficient } \\
\left(\mathbf{p}_{\mathbf{i j}}\right)\end{array}$ & \multicolumn{1}{|c|}{$\left(\mathbf{s b}_{\mathbf{i}}\right)$} & $\mathbf{t}_{\text {result }}$ & $\begin{array}{c}\mathbf{t}_{\text {table }} \\
(\boldsymbol{\alpha}=\mathbf{0 , 0 5})\end{array}$ & \multicolumn{1}{|c|}{ Conclusion } \\
\hline $\mathrm{X}_{1}$ to $\mathrm{X}_{2}\left(\mathrm{p}_{21}\right)$ & 0,486 & 0,0574 & 10,06 & 1,644 & Significant \\
\hline
\end{tabular}

The path coefficient value that shows the effect of motivation on proenvironmental behavior $\left(\mathrm{p}_{21}\right)$ is 0.486 . The results of this study indicate that there is a positive influence on students' motivation towards proenvironmental behavior owned by students of 0.486 . Most students of SMAN 1 Tangerang Regency have high motivation which influences the proenvironmental behavior of students. Students with high motivation will be more enthusiastic about students in environmental activities, love to protect the environment, strive to always take care of the environment, prioritize activities and environmental harmony and always carry out activities that have a positive impact on their environment. Starting from these desires students will tend to behave proenvironmental means that students will act something that has a positive impact on the surrounding environment.

These actions or behaviors can be in the form of students' behavior in saving energy, love the use of public transportation, behavior to reduce the amount of waste, love perilkau that is more environmentally friendly, save water energy and always try to reduce and reuse or recycle waste. This is in accordance with the opinion of Kollmus \& Agyeman (2002), 
which states that proenvironmental behavior is influenced by internal factors such as motivation to take action. This statement is also reinforced by the model of Mars (McShane \& Glinow, 2015) that the formation of a person's behavior can be influenced by several factors including: motivation, ability or ability, role perception or perspective and various situational factors.

Based on this research motivation becomes one of the drivers of students to act or behave. Motivation becomes an interest and the main reason for students to behave proenvironmental. This is consistent with the opinion of Pan (2010), which states that motivation is enthusiasm, incentives or interests that cause certain actions or certain behaviors to occur. besides Moses (2010) also argues that motivation is an encouragement for someone to behave in certain ways or take certain actions. Therefore, both theoretically and empirically student motivation has a positive direct effect on student environmental behavior

\section{CONSLUSION}

Based on the results of research and discussion, it can be concluded that motivation affects the proenvironmental behavior of students of SMAN 1 Tangerang Regency with path coefficients equal to 0.486 . This means that the direct effect of personality on proenvironmental behavior is 0.486 .

\section{REFERENCE}

Ariani, DW. 2013. Personality and Learning Motivation. European Journal of Business and Management. 5 (10): 26-38.

Dale H. Schunk, 2008. Learning Theories an Education perspective, $6^{\text {th }}$ Edition. New York: Pearson Education Inc.

Gifford, R., \& Nilsson, A. 2014. Proenvironmentalal concern and behaviour: A review, International Journal of Psychology: 1-17. http://doi: 10.1002/ijop.12034.

Kalat, James W. 2013. Biological Psychology, $11^{\text {th }}$ Edition, International Edition. China: Cengage Learning.

Kollmuss, A., \& Agyeman, J. 2017. Mind the Gap : Why do people act environmentally and what are the barriers to proenvironmentalal behavior? Mind the Gap : why do people act environmentally and what are the barriers to proenvironmentalal behavior. Environmental Education Research 8 (3). 239-260. http://doi: $10.1080 / 13504620220145401$ 
Krajhanzl, J. 2010. Environmental And Pro Environmental Behavior. School and Health. $251-274$.

Kurisu, K. 2015. Pro Environmental Behaviors. Springer. Tokyo: Departement of Urban Engineering, The University of Tokyo.

Lai, E. R. 2011. Motivation : A Literature Review Research Report. London: Pearson.

Latif, A.A., Damar, M.S., Bin, Y.H., Awang, Z. 2013. Role of environment knowledge in Creating Pro Environmental Residents. Procedia Social And Behavioral Sciences. 105: 866-874. http://doi: 10.1016/j.sbspro.2013.11.088.

Leeuw, A. De, \& Schmidt, P. 2015. Using the theory of planned behavior to identify key beliefs underlying pro- environmental behavior in high-school students. Journal of Environmental Psychology, 42: 28-138. https://doi.org/10.1016/j.jenvp.2015.03.005.

Lindenberg, S., 2001. Intrinsic motivation in a new light. Kyklos. 54 (2): 317-342. https://doi.org/10.1111/1467-6435.00156.

Linder, S.V.J. 2015. Intrinsic motivation and proenvironmentalal behaviour. Nature Climate Change 5: 612-613.

Luthans, F. (2006). Perilaku Organisasi. Edisi Sepuluh. Yogyakarta: Penerbit ANDI

Lynn, P. 2014. Distinguishing Dimensions of Proenvironmentalal Behaviour. University of Essex: Institute for Social and Economic Research.

Matsumo, D \& Juang, L. Culture And Psychology. $5^{\text {th }}$ Edition. Canada: Wadsworth Cengange Learning.

Manolas, E., \& Ph, D. 2015. Promoting Proenvironmentalal Behavior : Overcoming Barriers, AEJES 1: 13-21.

McShane, S. L., \& Von Glinow, M. A. 2010. Organizational Behavior: Emerging Knowledge and Practice for The Real World (5th ed.). New York: The McGraw-Hill Companies, Inc.

Newman, B.M. \& Newman, P.R. 2012. Life-Span Development A Psycholosial Approach. Brazil: Wadsworth Cangange Learning.

Reiss, S. 2012. Intrinsic and Extrinsic Motivation. Teaching of Psychology. 39(2):152-156. http://doi: 10.1177/0098628312437704

Riduwan. 2008. Skala Pengukuran Variabel- Variabel Penelitian. Bandung: Remaja Rosdakarya. 
Ryan, R. M., \& Deci, E. L. 2000. Intrinsic and Extrinsic Motivations : Classic Definitions and New Directions. Contemporary Educational Psychology 67: 54-67. http://doi:10.1006/ceps.1999.1020.

Schultz, P.W. 2000. Empathizing with nature: The Effects of Perspective Taking on Concern for Environmental Issues. Journal of Social Issues. 56: 39-46.

Schunk, Dale H. 2012. Learning Theories an Educational Perspective, terjemahan Eva Haamidah dan Rahmat Fajar. Yogyakarta: Pustaka Pelajar.

Steg, L., \& Vlek, C. 2009. Encouraging proenvironmentalal behaviour: An integrative review and research agenda. Journal of Environmental Psychology, 29 (3): 309-317. http://doi: 10.1016/j.jenvp.2008.10.004.

Sugiono, 2017. Statistik Untuk Peneitian. Bandung: Alfabeta.

Tabernero, C. and Bernardo, H. 2011. Self-Efficacy and Intrinsic Motivation Guiding Environmental Behavior. Environment and Behavior . 43 (5): 658- 675. https://doi.org/10.1177/0013916510379759.

Werff, E.V.D., Steg, L., Keizer, K. 2013. It is a moral issue: The relationship between environmental self-identity, obligation-based intrinsic motivation and proenvironmentalal behaviour . Global Environmental Change. 1115: 2-9. http://doi: 10.1016/j.gloenvcha.2013.07.018. 